\title{
Jędrzej Skrzypczak, Polityka medialna w okresie konwersji cyfrowej radiofonii i telewizji, Wydawnictwo Naukowe WNPiD UAM, Poznań 2011, ss. 498.
}

Przedmiotem pracy Jędrzeja Skrzypczaka stała się polityka medialna w okresie konwersji cyfrowej radiofonii i telewizji. W jej treści Autor postawił sobie za cel zbadanie analizy wpływu cyfryzacji na różne płaszczyzny polityki medialnej. Wybór tematu należy uznać za właściwy i dotyczący istotnej problematyki nie tylko z punktu widzenia teoretycznego, ale praktycznego. Układ treści pracy i prowadzenie wywodów należy uznać za wzorcowe i wzorowe. Autor zgrupowal materiał w pięciu rozdziałach rozbitych na mniejsze części i poprzedzone warsztatowym wstępem, w którym wyjaśniono tytuł pracy, określono jej granice rzeczowe, chronologiczne i terytorialne, sformułowano wyraźnie tezę pracy, hipotezy i pytania badawcze. Omówiono także, i to w sposób kompetentny i szczegółowy, metodologię pracy oraz scharakteryzowano jej źródła i wykorzystane opracowania. Piszący te słowa od dawna nie mial przyjemności czytać tak dobrze napisanego i wyczerpującego wstępu. Zamyka pracę świetnie napisane syntetyczne zakończenie, a uzupełnia ją prawidłowo zbudowana obszerna bibliografia (s. 437-498), na którą złożyły się źródła podzielone na odpowiednie dzialy wraz z orzecznictwem i opracowania. Recenzent z radością odnotowuje fakt, iż wreszcie ktoś z politologów w sposób właściwy konstruuje materiał bibliograficzny.

Wbrew ewentualnym oczekiwaniom, praca nie dotyczy wyłącznie polskiej polityki medialnej, gdyż ta stanowi jedynie wycinek polityki europejskiej. Mając na względzie uwarunkowania i zobowiązania międzynarodowe Polski Jędrzej Skrzypczak słusznie odwołał się do treści zawartych w dokumentach Organizacji Narodów Zjednoczonych czy UNESCO. Słusznie też poddal analizie działalność takich organizacji jak Światowa Organizacja Własności Intelektualnej oraz Światowa Organizacja Handlu. Szczególną uwagę poświęcił badaniu aktywności Rady Europy oraz Unii Europejskiej. Dobrze też, że wspomnial o osiaggnięciach Organizacji Bezpieczeństwa i Współpracy w Europie w dziedzinie mediów. Glówną hipotezą pracy jest twierdzenie, iż cyfryzacja mediów powinna być rozpatrywana na tle zjawiska konwergencji, ale zarazem dywergencji przekazywanych treści. Powyższe procesy rzutuja nie tylko na sferę technologii, ale także prawa, ekonomii oraz zachowań społecznych. Stąd też konieczna okazała się redefinicja głównych założeń polityki medialnej. Tym bardziej, że digitalizacja tego sektora wymaga nowego, bardziej elastycznego podejścia regulacyjnego. Autor rozważal czy w tej sytuacji można reformować dotychczasowe instytucje regulujące, czy raczej należy wykreować nową, kompleksową strategię, czego konsekwencją byloby stworzenie nowego prawa medialnego.

W pierwszym z rozdziałów pracy ukazano zjawisko cyfryzacji i jej wpływ na radiofonię i telewizję. Podjęto tu przede wszystkim próbę zdefiniowania terminu cyfryzacja, wskazując na wieloaspektowość tego pojęcia. Dalej opisano genezę i najważniejsze etapy rozwoju cyfrowych technologii medialnych, a także wlaściwości i mechanizmy funkcjonowania nowych mediów. W następnej części tego rozdziału, przybliżono takie istotne terminy związane z cyfryzacja, jak m.in. ,,multipleks”, ,interfejs aplikacji użytkownika”, ,elektroniczne przewodniki programowe”, ,systemy warunkowego dostępu”, „kompresja sygnału”, ,usługi dodatkowe”. Zwrócono uwagę również na konsekwencje zjawiska dywergencji przekazów cyfrowych, wskazując możliwe platformy dystrybucji przekazywanych treści. W rozdziale tym - w zakresie niezbędnym do wyjaśnienia zachodzących procesów - przybliżono kwestię funkcjonujących standardów technicznych emisji cyfrowych. W zakończeniu 
tej części pracy, podjęto próbę scharakteryzowania polskiego rynku mediów elektronicznych w okresie konwersji analogowo-cyfrowej. W ten sposób zamierzano uświadomić, jak rozległe będą musiały być zmiany rynkowe, wynikające $z$ wprowadzenia technologii digitalnych i jak rozległe mogą być konsekwencje decyzji politycznych w tym obszarze.

W rozdziale drugim skoncentrowano się na analizie instrumentów polityki medialnej państwa, wskazując dopuszczalne i niezbędne obszary oraz metody ingerencji w erze cyfrowej. W związku z tym, podjęto próbę przybliżenia istotę zjawisk określanych jako, ,samoregulacja” lub „,wspólregulacja”. Przedstawił tu także Jędrzej Skrzypczak podstawowe zasady transformacji cyfrowej takie jak neutralność technologiczna i interoperacyjność. Zaprezentowano w tym miejscu różne spotykane na świecie strategie przejścia z nadawania analogowego w cyfrowe. Na tym tle podjęto próbę zrekonstruowania europejskiej i polskiej polityki medialnej dotyczących konwersji cyfrowej radiofonii i telewizji. Wskazano nadto planowane horyzonty czasowe tego przejścia, jak również antycypowano jego konsekwencje społeczne, prawne i ekonomiczne. Rozdział trzeci stanowi próbę ukazania wpływu digitalizacji na regulację treści programów radiowych i telewizyjnych. Zwrócono tu uwagę, że opisywane zjawiska powodują liczne problemy definicyjne dotyczące terminów tak podstawowych dla poruszanej problematyki jak ,prasa”, ,radio” i ,telewizja”. Dostrzeżono także nowe zagrożenia dla wolności słowa, jakie wynikaja z postępu technologicznego, a także konieczność dostosowania instytucji prawa prasowego ukształtowanych w okresie przedcyfrowym do specyfiki nowych mediów. Poruszono w nim także kwestię wpływu technologii na status zawodowy dziennikarzy oraz zjawisko koncentracji mediów w erze cyfrowej. Na tym tle Autor zaprezentował rozważania na temat szans i zagrożeń dla radiofonii i telewizji publicznej w nowej rzeczywistości. Na koniec poruszono problematykę finansowania działalności nadawczej. W rozdziale czwartym Jędrzej Skrzypczak skupił się na zadaniach państwa w obszarze regulacji sposobów i technologii przekazywania sygnałów radiofonii i telewizji cyfrowej. Wykazał, iż sprawą niezwykle istotną jest rozstrzygnięcie kwestii modelu oraz roli i zadań regulatora rynku w erze cyfrowej. Zwrócił uwagę na konieczność zredefiniowania paradygmatów polityki gospodarowania widmem radiowym. W kolejnym piątym rozdziale ukazano problematykę wpływu cyfryzacji na ochronę własności intelektualnej. Dokonano w nim przeglądu międzynarodowych, europejskich i krajowych instrumentów prawnych chroniących nadawców pod kątem ich przystosowania do nowej rzeczywistości technologicznej. Autor zwrócił uwagę, że w kontekście koncepcji ochrony własności intelektualnej wattpliwości wzbudza już samo pojęcie ,nadanie”. Prowadziło Go to do rozważań nad zakresem uprawnień podmiotów uprawnionych, dozwolonego użytku z chronionych utworów, technicznych środków zabezpieczających oraz roli organizacji zbiorowego zarządzania prawami.

Zamyka pracę syntetyczne, treściwe, ale bardzo istotne zakończenie, w którym Autor wykazuje, że cyfryzacja mediów, będąca w istocie jedynie procesem technicznym, wywołuje ogromne skutki nie tylko w sferze technologii, ale także zachowań społecznych, ekonomii i prawa. W tej sytuacji konieczne jest przede wszystkim rozstrzygnięcie jaki model polityki medialnej winien być obowiązującym, czyli jakie stanowisko zająć w kwestii regulacji systemu medialnego, a zatem jak glęboka winna być interwencja państwa. Choć akcentowane jest obecnie przekonanie, że konieczna jest deregulacja, to jednak opowiedzieć należy się raczej za re-regulacją. Z pewnością państwo nie może bowiem zrezygnować z podjęcia najważniejszych decyzji odnoszących się do cyfryzacji, takich jak stworzenie planu i strategii $s \sim$ witchover, ustalenia i nadzorowania harmonogramu transformacji cyfrowej, 
ale także rozwiązania problemu finansowania procesu konwersji, w szczególności rozstrzygnięciem kwestii, kto powinien ponieść koszty transformacji, a wreszcie przesądzeniu, jak powinna zostać rozdystrybuowana dywidenda cyfrowa. Autor słusznie podkreśla, że należy zmierzać w kierunku forsowania zasad neutralności technologicznej i interoperacyjności oraz eliminacji tzw. bram cyfrowych, czyli dyskryminujacych zasad funkcjonowania takich elementów składowych przekazów cyfrowych, jak chociażby elektroniczne przewodniki programowe, systemy warunkowego dostępu, interfejs programu aplikacyjnego. W przeciwnym razie dojść może do zmonopolizowania dostępu do przekazywanych treści. Zadaniem państwa jest - jak wywodzi Jędrzej Skrzypczak - także międzynarodowa koordynacja gospodarki widmem radiowym, niezbędna do uruchomienia krajowych nadań cyfrowych, przygotowanie planu zagospodarowania częstotliwości, a także wprowadzenia standaryzacji technologicznej oraz określenie warunków technicznych i eksploatacyjnych urządzeń odbiorczych używanych przez konsumentów. Polityka medialna powinna także przeciwdziałać wykluczeniu cyfrowym. Oznaczać to powinno podjęcie aktywnych działań w zakresie pomocy osobom, które nie są w stanie sprostać wymaganiom technicznym i jak również ekonomicznym. Konieczne jest także wdrożenie odpowiedniej strategii informacyjnej, której celem powinno być edukowanie obywateli w zakresie umiejętności posługiwania się nowymi technologiami. W toku rozważań udało się Autorowi wykazać, że jedną z najważniejszych konsekwencji opisywanej mediamorfozy, jest zjawisko konwergencji przekazów medialnych, które należy wiązać z dywergencją tychże. Powyższe procesy oznaczają nie tylko zbliżenie odrębnych do tej pory obszarów takich jak media, telekomunikacja oraz komputery. Wydaje się bowiem, że zmiany technologiczne muszą wywrzeć również piętno nie tylko na technicznych aspektach komunikowania, ale również na instytucjonalnym kształcie systemu medialnego. To powinno w konsekwencji prowadzić do reorientacji i redefinicji celów strategicznych polityki medialnej. Konwergencja technologiczna musi iść w parze z konwergencją regulacyjna, bowiem czynniki obiektywne w postaci dokonującej się ,rewolucji cyfrowej” decyduja, że utrzymywanie odrębnego podejścia ustawodawcy do wymienionych wyżej sektorów traci sens. Stąd też opowiedzieć należy się za modelem tzw. regulacji poziomej, rezygnując ze schematu pionowego, odrębnego dla każdej płaszczyzny, co było charakterystyczne dla ery analogowej. Jędrzej Skrzypczak słusznie wskazuje, że projektując założenia polityki medialnej, należy uwzględnić zjawisko dywergencji w tym znaczeniu, iż podejście regulacyjne musi mieć na uwadze zróżnicowany charakter poszczególnych platform dystrybucji treści. Stąd też bardzo ciekawym rozwiązaniem jest koncepcja proporcjonalności, podkreślająca postulat wprowadzenia dywergencji regulacyjnej w zależności od rodzajów przekazów. Wskazuje, że na płaszczyźnie ogólnodostępnych bezprzewodowych programów naziemnych proponuje się pełną regulację w postaci zbliżonej do dzisiejszego modelu radiofonii i telewizji. Argumentem przemawiającym za takim rozwiązaniem jest twierdzenie, że nadawcy otrzymują w tym przypadku dobro ograniczone w postaci częstotliwości radiowych, stąd też i wymagania kierowane do takich podmiotów mogą być większe. Ponadto możliwość korzystania z takich przekazów musi być w pełni powszechna. W przypadku platform satelitarnych, do których dostęp jest zazwyczaj płatny, a więc w pewnym sensie limitowany, odbiorcy dokonują świadomego wyboru, zatem proponuje się regulację ograniczoną do np. spraw obyczajowych. Wreszcie w przypadku przekazów internetowych postuluje się w zasadzie jedynie samoregulację oraz zapewnienie skutecznych środków ochrony prawnej podmiotów prawa. Z pewnością nie ma tu potrzeby ani konieczności, aby sięgać po takie instrumenty, jak chociażby koncesje 
lub zezwolenia. Tym bardziej, że nie ma to przyzwolenia społecznego. Choć jest to zupełnie nowy sposób komunikacji, to utrwaliło się już powszechne przekonanie o przysługującej niemalże absolutnej wolności w tym obszarze. Nie może to oznaczać oczywiście przyzwolenia na anarchię i naruszenie wolności i praw innych podmiotów, ale ingerowanie organów państwa w tę sferę powinno być niezwykle rozważne i ograniczone. Zdaniem Jędrzeja Skrzypczaka jako niedopuszczalne ocenić należy te wszystkie działania, które w istocie mogłyby być potraktowane jako forma cenzury prewencyjnej. Zważywszy na powyższe wydaje się również, że model regulatora rynku powinien zostać dostosowany do cyfrowej rzeczywistości konwergentnej. Ponownej analizy wymaga także kwestia zakresu przedmiotowego i podmiotowego koncesjonowania nadawania. Za niezbędne uznaje się także konieczność zredefiniowania istniejących pojęć takich jak prasa, radiofonia i telewizja oraz wyjaśnienia nowych terminów takich jak chociażby multipleks. Dostosowania do nowej rzeczywistości technologicznej wymagają także takie instytucje jak sprostowania i odpowiedzi prasowe oraz autoryzacja. Wydaje się, że przedefiniowania wymaga również status zawodowy dziennikarza. Na nowo należy także spojrzeć na problem koncentracji mediów. Reakcji ustawodawcy wymagają pojawiające się formy finansowania działalności nadawczej, a w szczególności reklamowania oraz ochrony własności intelektualnej. Odrębnym problemem jest funkcjonowanie mediów publicznych, których dalsze istnienie jest dziś bardziej kategorią polityczną niż technologiczną. Opowiadając się za modelem tzw. pełnej oferty funkcjonowania systemu mediów publicznych Autor podkreśla konieczność przebudowy tych mediów. Zwraca shusznie uwagę, że nadawcy publiczni winni gwarantować wysoki poziom wiarygodności, jakość oraz niezależność przekazywanych treści, dostęp do rzetelnych informacji, debat uwzględniających interesy krajowe i ich artykułowanie szerszej publiczności, dostęp ogółu społeczeństwa do dobrodziejstw wynikających z ery cyfrowej, wypełnianie luk w ofercie nadawców komercyjnych, promowanie tożsamości kulturowej i ochrony języka narodowego, a także krajowej i europejskiej produkcji audiowizualnej oraz rozwój i innowacyjność społeczeństwa. Zdaniem Jędrzeja Skrzypczaka należy w tej chwili zamiast mówić o radiofonii i telewizji publicznej należy odnosić się do mediów publicznych, których treści winny być dostępne na wszystkich płaszczyznach. Uwzględniając specyfikę ery konwergencji i dywergencji przekazów Autor słusznie opowiada się za utworzeniem jednego podmiotu funkcjonującego na wszystkich dostępnych płaszczyznach dostępu do treści. Zwraca uwage, że zapewnić to może bardziej efektywne wykorzystanie środków publicznych i obniżenie kosztów obsługi ,misji publicznej”. Najlepiej do wyzwań cyfryzacji dostosowana jest sfera ochrony własności intelektualnej. Aczkolwiek i tu są pewne obszary ,zaniedbań” i opóźnień. Za takie będzie z pewnościa uchodzić brak międzynarodowej konwencji chroniącej nadawców w erze cyfrowej, a na gruncie krajowym w szczególności pewien bałagan terminologiczny.

Jęrzej Skrzypczak podkreśla, że bez nowej polityki medialnej, bez pomocy państwa, część spoleczeństwa może zostać wykluczona z dobrodziejstw, jakie niesie ze sobą rewolucja cyfrowa. Zauważa, iż konwersja cyfrowa sprawia, że po wyłączeniu emisji analogowych sygnału telewizyjnego, niektóre osoby mogą zostać pozbawione całkowicie dostępu do mediów. Stąd też polityka medialna musi brać pod uwagę nie tylko kwestie technologii, ale także konsekwencje społeczne i ekonomiczne opisywanych procesów. Dlatego też konieczne jest, aby pośród priorytetów strategii państwa uwzględnić rozwiązania przeciwdziałające wykluczeniu cyfrowemu, ale także osłabieniu tożsamości kulturalnej, narodowej i spójności społecznej. 
Zgadzając się generalnie z tezami i hipotezami Jędrzeja Skrzypczaka z obowiązku recenzenckiego wypada zwrócić uwagę na niezwykle bogatą dokumentację wywodów w przypisach, które nie mają charakteru odsyłającego, a erudycyjny, dowodząc tym samym głębokiej eksperiencji Autora w zakresie podjętego tematu.

Oceniana rozprawa jest dziełem oryginalnym, wyraźnie wzbogacającym dorobek polskiej literatury naukowej. Autor jej, zarówno w toku wywodów, jak i w końcowej obszernej analizie dowiódt, że jest inteligentnym, kompetentnym badaczem, który w polu swoich dociekań porusza się z dużym znawstwem i swoboda, prezentując świetną znajomość analizowanej problematyki. Podjął On ważne zagadnienia badawcze, mieszcząc e się w obszarze zainteresowań kilku gałęzi i dyscyplin naukowych. Praca Jędrzeja Skrzypczaka wydaje się w równym stopniu mieścić w płaszczyźnie badań politologicznych, co prawniczych, przy czym jest doskonale osadzona zarówno w tekstach prawniczych, jak i politologicznych. Podziwiać należy umiejętność Autora poruszania się w polu tak odległych dyscyplin. Autor wykazal się umiejętnością sformułowania oryginalnego problemu naukowego, dostosowania go do logicznego rozwiązania konstrukcji wywodu oraz konsekwencją badawczą w prezentacji problemu. W rezultacie zostało przygotowane i przedstawione wartościowe poznawczo i w gruncie rzeczy - nowatorskie w literaturze polskiej ujęcie problematyki funkcjonowania KRRiT. Treść ocenianej pracy jest wyjątkowo solidnie udokumentowana. Autor, co istotne, zajmuje częstokroć krytyczne stanowisko, wobec opinii innych autorów, które konfrontuje, podziela, poddaje w wątpliwość, bądź odrzuca, jeśli nie wytrzymują krytyki. Posługuje się bogatym językiem. Praca dowodzi dużej wiedzy politologicznej i prawniczej Autora oraz sprawności intelektualnej. W sumie jednak należy stwierdzić, że przedstawiona praca jest dziełem oryginalnym, wyraźnie wzbogacającym dorobek polskiej literatury z zakresu politologii i prawa konstytucyjnego. Czytelnik monografii Jędrzeja Skrzypczaka raz jeszcze przekonać się może, że dominującą cechą Jego twórczości naukowej jest rzetelność badawcza połączona z ostrożnością wniosków, jasnością sądów i głębią refleksji. Łączy to Opiniowany z krytycznym stosunkiem do ustaleń poprzedników i dążeniem do konfrontacji obrazu wyłaniającego się z przekazów źródłowych i ze świadectwami praktyki. Cechująca Go ostrożność poznawcza wyraża się w unikaniu sądów ogólniejszej natury nieznajdujących potwierdzenia w materiale źródłowym, umiejętność syntezy oraz jasność wykładu. Książka Polityka medialna w okresie konwersji cyfrowej radiofonii i telewizji wnosi istotny wkład do badań politologicznych oraz prawnoustrojowych.

Jacek SOBCZAK

Szkoła Wyższa Psychologii Społecznej, Warszawa 